\title{
Influence of Water Harvesting Practices on Farmer's Productivity in Semi-Arid Areas of Nigeria
}

\author{
Johnson Kayode Adewumi ${ }^{1}$, Adeyinka Sobowale ${ }^{1}$ and Are Kolawole ${ }^{2}$ \\ 1. Department of Agricultural and Bioresources Engineering, Federal University of Agriculture, Abeokuta 110001, Nigeria \\ 2. Faculty of Management and Social Sciences, Ibrahim Badamosi Babangida University, Lapai 911101, Nigeria
}

\begin{abstract}
Rain water harvesting practices and their effects on the productivity of farming systems in the semi-arid areas of Nigeria have been investigated using participatory rural appraisal (PRA) technique. There was no direct water harvesting interventions by government agencies in the area. Farmers take advantage of naturally existing depressions and abandoned burrow pits close to their farmlands to harvest rain water for surface irrigation using petrol engine pumps. The reservoirs surveyed were found to be grossly inadequate in the drought period. Water budget analysis revealed that evaporation and seepage losses from reservoirs were high in both agro-ecological zone considered. The application of rain water harvesting practices was found to have increased farmers income by $61 \%$ and $125 \%$ in the Sahel and Sudan Savannah agro-ecological zones, respectively. Governments at all levels in these areas need to support these farmers in order to boost their production to achieve food security in these drought prone areas. Farmers lack timely access to farm credit and agricultural inputs; the indigenous water harvesting practices identified need to be enhanced with the aid of agricultural engineering extension services.
\end{abstract}

Key words: Rainfall, water harvesting, irrigation, drought, productivity, farming systems.

\section{Introduction}

The most important external environmental effects on agriculture are related to the availability and quality of water. Water is essential to maximize both crop yield and quality; this resource has assumed tremendous importance, especially in the semi-arid areas of Nigeria, where drought and environmental degradation has seriously affected agricultural production and livelihood. There are many indications that water is becoming an increasingly scarce resource $[1,2]$ and surface water and groundwater flows are changing due to changes in climate and land use in Nigeria. Access to water is now recognized as a prerequisite for poverty reduction [3] and it is the most important determinant of increase in agricultural output and rural development.

As a result of lack of adequate infrastructure in

Corresponding author: Adeyinka Sobowale, Ph.D., research fields: land and water engineering. E-mail: sobowalea @)funaab.edu.ng.
Northern Nigeria, farmers still draw water from rivers for domestic and agricultural uses [4]. While datasets relating to surface water resources, land-cover and areas equipped for irrigation are said to be available [5], the relative contribution of irrigation to agricultural production is still subjective in Nigeria [6]. However, it should be pointed out that despite the relatively small productivity extent of groundwater irrigation compared to conventional rain fed farming and surface/gravity flow irrigation, especially in the rain forest and Guinea Savannah region of Nigeria, it represents a unique alternative for management of scarce water resources in support of small scale agricultural production and rural livelihoods in drought prone areas of the country.

The Natural Resources Council of Nigeria (NARESCON) describes drought-prone areas in Nigeria as those lying above latitude $11^{\circ}$ North in the country [7]. The area comprises of the Sudan Savannah and the Sahel Savannah agro-ecological zones of Nigeria (Fig. 1). The changing trend of global 


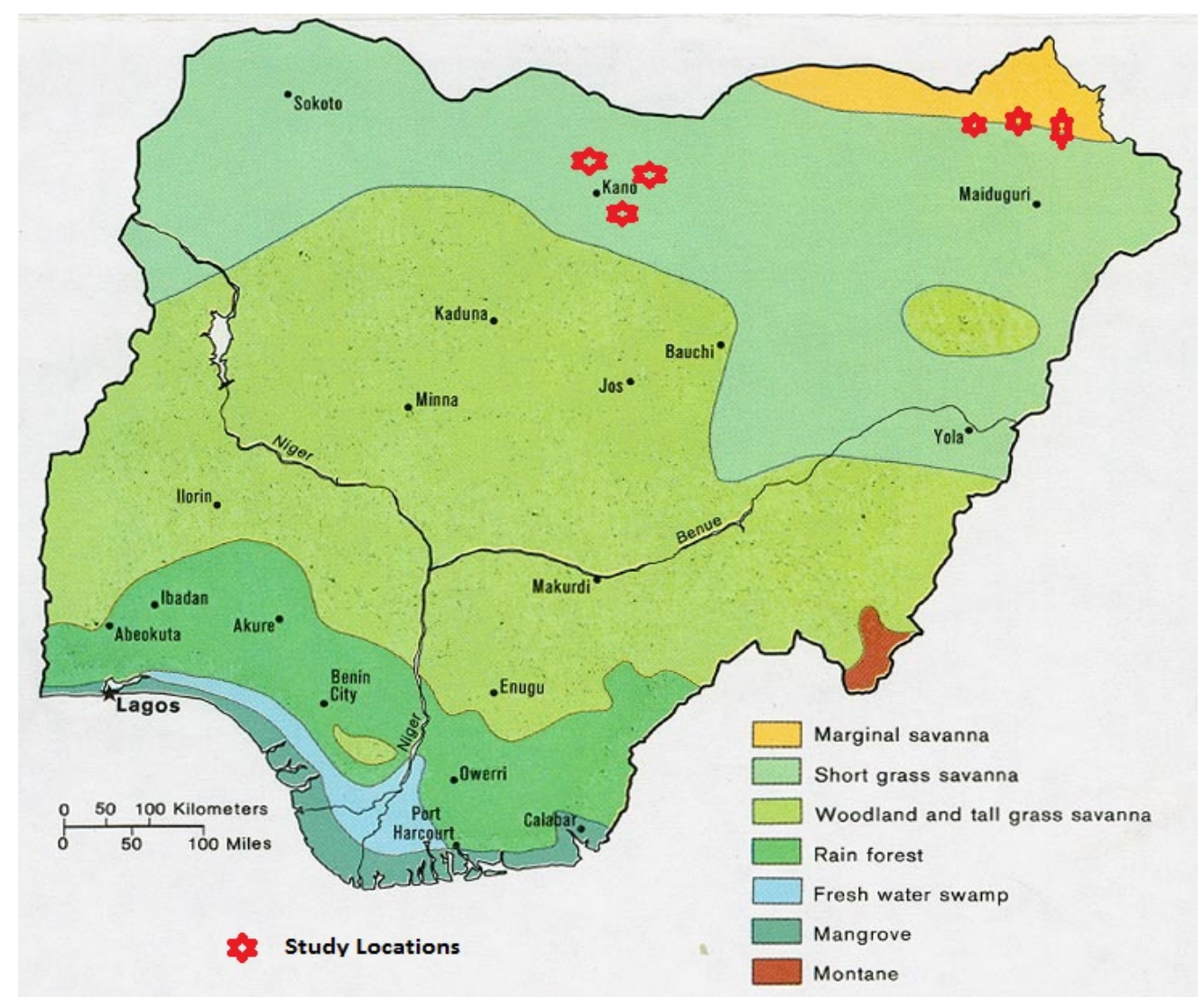

Fig. 1 Agro-ecological zones in Nigeria.

climate and the effect of desertification in these parts of the country have exerted pressure on the available water resources. Crop production in Nigeria is predominantly rain-fed; there is so much dependence on the 6-8 months of rainfall which varies in intensity and distribution all over the country. The harvesting of excess rainfall (runoff) during the wet season for use in the dry season will help increase the cropping period that the farmers engage the land, which in turn can be expected to translate into increased income for the farmers. In the semi-arid areas where it is already been practiced, water harvesting is a directly productive form of soil and water conservation. The United Nations Food and Agriculture Organization (FAO) have estimated that almost 200 million Africans were undernourished at the dawn of the millennium, compared with 133 million 20 years earlier [8]. The only way to reduce this food insecurity is to find ways of improving the productivity of existing farming systems especially in the drought prone areas. Water harvesting therefore, is a means by which food production can be scaled up in these areas.

The objective of this study was to investigate the adoption of water harvesting practices and to elucidate that such adoption have an effects on the productivity of available farming systems in the drought-prone areas of Nigeria.

\section{Materials and Methods}

The study was carried out in the Sudan and Sahel Savannah agro-ecological zones of Nigeria. Three village sites each were randomly selected in each zone for study, and the geographic location of the sites and rainfall and temperature ranges are given in Table 1 . The participatory rural appraisal (PRA) technique [9] was used to obtain relevant information for the study. This involves: (1) analysis of available secondary data from the area, such as soil maps, weather records, 
demographic data and socio-economic data; (2) direct observation of field objects, people, event, processes, and relationship. Focused group discussions were also held with farmers and the traditional institutions using structured questionnaires. Plot size sample surveys were also carried out for information on farming operations.

Water harvesting reservoirs in the study sites were surveyed for capacity (available water $(A W)$ ) and catchment area. Water balance analysis of the water harvesting reservoirs was also carried out to evaluate their adequacy for the drought period using the water budget (WB) model stated in Eq. (1). The water demand (WD) considered in the analysis include: livestock use, evaporation, seepage, irrigation and domestic water use where applicable. Potential evaporation $\left(E T_{o}\right)$ at the reservoir sites was estimated using Blaney-Criddle model stated in Eq. (2) [10]; infiltration rate at the reservoir floor was determined using a double ring infiltrometer and used to estimate seepage rate $(S R)$; livestock use (LWR) was based on estimate of livestock population and daily water requirement for each livestock; irrigation needs (IWR) was estimated using FAO daily water requirement of crops planted at the sites; domestic water use (DWR) was estimated using population figures of the villages where applicable:

$$
\begin{aligned}
W B & =A W-W D \\
& =A W-\left(E T_{o}+I W R+L W R+S R+D W R\right)
\end{aligned}
$$

Positive values of $W B$ shows water surplus, while negative values shows water deficit:

$$
E T_{o}=P(0.46 T+8.13)
$$

where, $P$ is the mean daily percentage of annual daytime hours (\%), $T$ is the mean air temperature $\left({ }^{\circ} \mathrm{C}\right)$.

Farming system productivity was determined using farm budget analysis of the data collected from randomly selected farmers, the model used is stated in Eq. (3):

$$
N F I=T R-(T V C+T F C)
$$

where, $N F I=$ net farm income in Naira ( $)$; $T R=$ total revenue in Naira ( $)$; TVC = total variable cost in Naira ( $)$; TFC = total fixed cost in Naira ( $)$.

The farming systems considered include: rain-fed farming (FS I), farming with water harvesting (FS II) and irrigation farming (FS III).

\section{Results and Discussion}

Tables 2 and 3 present the identified farming systems and the types of crops grown in the Sudan and Sahel Savannah, respectively. The farming systems in the Sudan Savannah were found to be less complex and consist largely of rain fed (tudu) farming, valley bottom (fadama) farming and irrigation farming. Irrigation farming in the area can be classified into three depending on the source of water and the scale of practice: rain water harvesting (drawing water from burrow pits), use of tube wells and wash bores, and formal public scheme such as the Kano River Irrigation Project (KRIP) and the Hadejia Valley Project (HVP).

The sites in the Sahel Savannah revealed a farming pattern which is influenced by the presence of the

\begin{tabular}{|c|c|c|c|}
\hline Agro-ecological zone & $\begin{array}{l}\text { Village } \\
\text { (Local government area, state) }\end{array}$ & Location & Climate \\
\hline Sahel Savannah & $\begin{array}{l}\text { Kaje (Marte, Borno) } \\
\text { Kolbe (Dikwa, Borno) } \\
\text { Mafa (Mafa, Borno) }\end{array}$ & $\begin{array}{l}\text { Latitude } 12^{\circ} 20^{\prime} \mathrm{N} \text {, longitude } 14^{\circ} 11^{\prime} \mathrm{E} \\
\text { Latitude } 11^{\circ} 58^{\prime} \mathrm{N} \text {, longitude } 13^{\circ} 50^{\prime} \mathrm{E} \\
\text { Latitude } 11^{\circ} 53^{\prime} \mathrm{N} \text {, longitude } 13^{\circ} 45^{\prime} \mathrm{E}\end{array}$ & $\begin{array}{l}\text { Rainfall: } 250-500 \mathrm{~mm} \\
\text { Tempeture: } 24-27^{\circ} \mathrm{C}\end{array}$ \\
\hline Sudan Savannah & $\begin{array}{l}\text { Tarau (Bebeji, Kano) } \\
\text { Wangara (Tofa, Kano) } \\
\text { Kafur (Kafur, Katsina) }\end{array}$ & $\begin{array}{l}\text { Latitude } 11^{\circ} 42^{\prime} \mathrm{N} \text {, longitude } 08^{\circ} 40^{\prime} \mathrm{E} \\
\text { Latitude } 11^{\circ} 55^{\prime} \mathrm{N} \text {, longitude } 08^{\circ} 20^{\prime} \mathrm{E} \\
\text { Latitude } 11^{\circ} 40^{\prime} \mathrm{N} \text {, longitude } 07^{\circ} 40^{\prime} \mathrm{E}\end{array}$ & $\begin{array}{l}\text { Rainfall: } 800-1,000 \mathrm{~mm} \\
\text { Tempeture: } 29-35^{\circ} \mathrm{C}\end{array}$ \\
\hline
\end{tabular}
Lake Chad. The identified farms were found to be related to different soil types differentiated under the

Table 1 Location of study sites. 
Table 2 Identified farming systems in the Sudan Savannah.

\begin{tabular}{llll}
\hline Farming system & Local name & Crops cultivated & Cropping season \\
\hline FS I & tudu & $\begin{array}{l}\text { Crops are grown in combination: sorghum/groundnut, maize/cotton, } \\
\text { millet/sorghum/cowpea, sorghum/maize, cotton/cowpea, millet/groundnut }\end{array}$ & June-October \\
\hline FS II & fadama & $\begin{array}{l}\text { Tomatoes, pepper, onions, rice, carrot, lettuce, cabbage, garden egg, sugar } \\
\text { cane, wheat, maize, okro }\end{array}$ & January-December \\
\hline FS III & noman ruwa & Rice, wheat, tomatoes, pepper, onions & November-April \\
\hline
\end{tabular}

Table 3 Identified farming systems in the Sahel Savannah.

\begin{tabular}{llll}
\hline Farming system & Local name & Cultivated crops & Cropping season \\
\hline \multirow{4}{*}{ FS I } & kati kassa & Maize, sorghum, groundnut and cowpea & July-September \\
& kati kulum & Maize, cowpea, sorghum and rice & July-September \\
& kati kulum & $\begin{array}{l}\text { Cassava, cowpea, wheat, sorghum, maize, millet, tomatoes, garlic, sweet } \\
\text { potatoes, pepper, vegetables, sugarcane }\end{array}$ & July-September \\
& firki & Maskwa sorghum & August-January \\
\hline \multirow{2}{*}{ FS II } & fadama or firki & $\begin{array}{l}\text { Water melon, cassava, cowpea, wheat, sorghum, maize, millet, tomatoes, } \\
\text { garlic, sweet potatoes, pepper, vegetables, sugarcane }\end{array}$ & Garden egg, cassava, cowpea, wheat, sorghum, maize, millet, tomatoes, \\
& & garlic, sweet potatoes, pepper, vegetables, sugarcane & July-November \\
\hline \multirow{2}{*}{ FS III } & South Chad & Rice and wheat & December-June \\
\hline
\end{tabular}

lake regime by the local farmers into zuru (flooded) and kudu (non-flooded). Modern farming methods have emerged in the area by way of the use of tube wells and petrol engine pumps (fadama farming) and medium to large scale irrigation projects. The introduction of these systems has improved agricultural productivity and enhanced the farmer's income.

The survey revealed that the two agro-ecological zones are very rich in human resources for farming at both household and societal levels; the household is usually the main source of labour, accounting for about $70 \%$ of total labour requirement. The result also shows that the farm holding size depends on factors such as household size, occupational diversification and level of wealth. About $27.7 \%$ of the sampled household in the Sahel Savannah and 51.5\% in the Sudan Savannah contains 15-30 members; most of the sampled farmers have an average of 15 members within their household.

Farmer's access to agricultural land varies in both agro-ecological zones due to variations in prevailing land tenure system. Human population is sparse in the Sahel Savannah, hence the land is surplus; access to land is however a major problem in the Sudan Savannah due to high population density. The most productive land is the fadama or firki land to which access is very restricted and therefore its holdings are fragmented, especially in the Sudan Savannah.

\subsection{Rain Water Harvesting Practices}

The objective of water harvesting is to collect runoff and store it for use at the onset of the dry season for crop production, domestic use and livestock watering. The observations made in the Sudan and Sahel areas were that farmers take advantage of naturally existing depressions, ditches and burrow pits on highways close to their farms and villages. There was no government intervention or communal efforts for the construction of the water harvesting structures. It was also observed that there were no efforts directed at increasing the capacities of the burrow pits identified. Excess rainfall accumulates into the depressions and is eventually used for domestic use, livestock and small scale irrigation. Table 4 summarizes the water balance of the reservoirs surveyed in the Sudan and Sahel Savannah, respectively. The study revealed that the existing 
water harvesting structures in the area are highly inadequate for the dry season in the two agro-ecological zones. The water budget analysis show that the available water in the burrow pits can only sustain the identified uses for a period of three and half months and four months out of the existing seven months drought period in the Sudan and Sahel Savannah zones, respectively. Irrigation appears to be the largest water user in the Sudan Savannah area, while seepage and evaporative demand consume more water in the Sahel Savannah. Increasing the capacities of these structures and reducing seepage and evaporation will make the water to last longer. Evidences of poor sanitation were observed in some areas as the same ponds were used for livestock watering and human consumption. This increases the risk of exposure to water-borne diseases in the area. It is advised that separate ponds are constructed for domestic water source and simple water treatment technologies are introduced to the rural areas.

\subsection{Productivity of Farming Systems}

A comparison of the crop yield from the surveyed villages in the two agro-ecological zones is presented in Fig. 2. FS II and FS III appear to have the highest yield especially in the Sudan Savannah; this is probably due to the intensive nature of farming in the area.

The study revealed that FS I in the Sahel Savannah areas has very low external inputs. $90.7 \%$ of the total variable costs were expended on labour (household and hired), while $9.3 \%$ were expended on seed procurement. The net average household income was $\$ 7,566 / \mathrm{ha}$, and it should be noted that this value is based only on grains (maize and sorghum). In the Sudan Savannah on the other, average net household income was $\$ 20,889$ /ha for the same farming system. This is more than double the income for the Sahel zone and is probably due to more favourable climatic condition, intensive farming practices, mixed cropping and proximity to urban areas. Unlike the Sahel Savannah areas, FS I in the Sudan Savannah is characterized by high external farming inputs.

The water harvesting based FS II also proved to be dependent on low external inputs in the Sahel zone; labour and seed procurement accounted for $70 \%$ and $30 \%$ of the total variable costs, respectively. The average net household income of farmers practicing this system was $\$ 4,661 /$ ha. It is important to note that this system is only complimentary to the other farming systems and has resulted to increased income for the farmers; by this, farmers are able to engage the land for additional 3-4 months in the year. This indigenous farming system has fulfilled the need established by the FAO [11] for obtaining more crop yield for every drop of water used. In the Sudan Savannah however, the crops planted with this system include tomatoes, pepper, lettuce, and water melon etc., the average net household income was $\$ 26,171.27 / \mathrm{ha}$.

FS III in the Sahel Savannah areas was found to have produced an average net household income of

Table 4 Water balance of identified water harvesting reservoirs in the study areas.

\begin{tabular}{|c|c|c|c|c|c|c|c|c|c|c|}
\hline \multirow[t]{2}{*}{$\begin{array}{l}\text { Agro-ecological } \\
\text { zone }\end{array}$} & \multirow[t]{2}{*}{ Village } & $\begin{array}{l}\text { Livestock } \\
\text { use } \\
\left(\mathrm{m}^{3} / \text { day }\right)\end{array}$ & $\begin{array}{l}\text { Evaporation } \\
\left(\mathrm{m}^{3} / \text { day }\right)\end{array}$ & $\begin{array}{l}\text { Seepage } \\
\left(\mathrm{m}^{3} / \text { day }\right)\end{array}$ & $\begin{array}{l}\text { Irrigation } \\
\left(\mathrm{m}^{3} / \text { day }\right)\end{array}$ & $\begin{array}{l}\text { Domestic } \\
\text { water use } \\
\left(\mathrm{m}^{3} / \text { day }\right)\end{array}$ & $\begin{array}{l}\text { Total daily water } \\
\text { requirement } \\
\left(\mathrm{m}^{3} / \text { day }\right)\end{array}$ & $\begin{array}{l}\text { Seasonal water } \\
\text { requirement } \\
\text { (seven months) } \\
\left(\mathrm{m}^{3}\right)\end{array}$ & $\begin{array}{l}\text { Available } \\
\text { water } \\
\left(\mathrm{m}^{3}\right)\end{array}$ & $\begin{array}{l}\text { Water } \\
\text { balance } \\
\left(\mathrm{m}^{3}\right)\end{array}$ \\
\hline & & 1 & 2 & 3 & 4 & 5 & $6=1+2+3+4+5$ & 7 & 8 & $9=7-8$ \\
\hline \multirow{3}{*}{$\begin{array}{l}\text { Sudan } \\
\text { Savannah }\end{array}$} & Tarau & $17(15.5 \%)$ & $9(8 \%)$ & $0.9(0.8 \%)$ & $83(76 \%)$ & - & 109.9 & 23,079 & 3,500 & $-19,579$ \\
\hline & Wangara & $17(44 \%)$ & $15(38 \%)$ & $3(8 \%)$ & - & $4(10 \%)$ & 39 & 8,190 & 8,000 & -190 \\
\hline & Kafur & $17(40 \%)$ & $12(28 \%)$ & $1.4(4 \%)$ & $12(28 \%)$ & - & 42.4 & 8,904 & 4,500 & $-4,404$ \\
\hline \multirow{3}{*}{$\begin{array}{l}\text { Sahel } \\
\text { Savannah }\end{array}$} & Kaje & $10(18 \%)$ & $28(49 \%)$ & $19(33 \%)$ & - & - & 57 & 11,970 & 8,500 & $-3,470$ \\
\hline & Kolbe & $10(27 \%)$ & $14(37 \%)$ & $7(18 \%)$ & $7(18 \%)$ & - & 38 & 7,980 & 4,200 & $-3,780$ \\
\hline & Mafa & $10(14 \%)$ & $31(42 \%)$ & $19(26 \%)$ & $3(4 \%)$ & $10(14 \%)$ & 73 & 15,330 & 8,900 & $-6,430$ \\
\hline
\end{tabular}




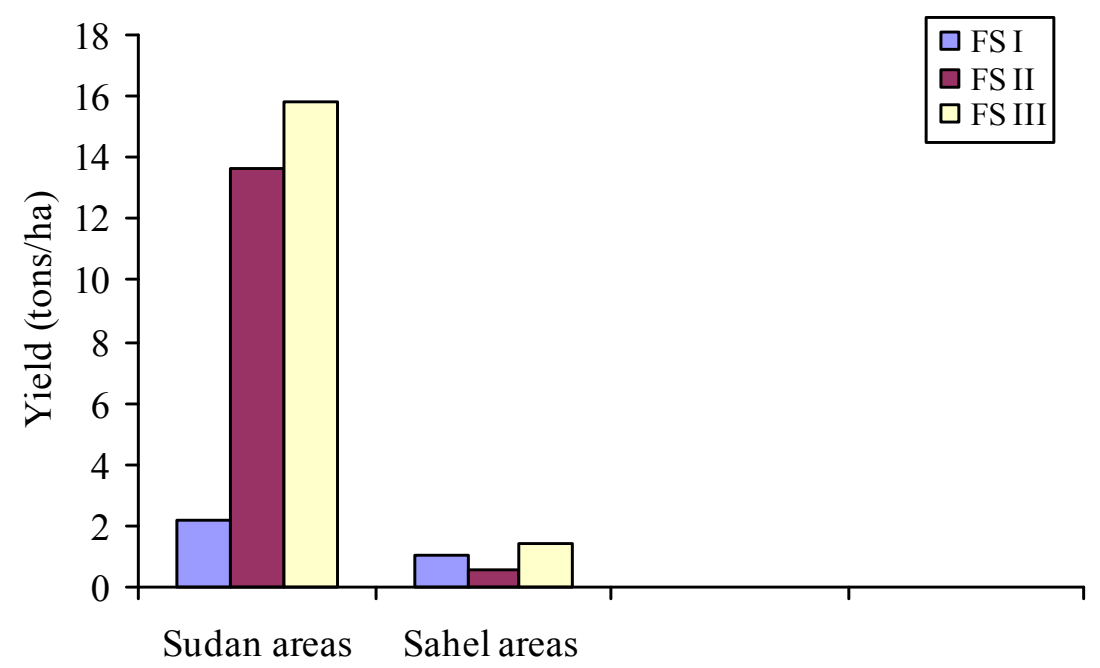

Fig. 2 Comparison of crop yield from farming systems.

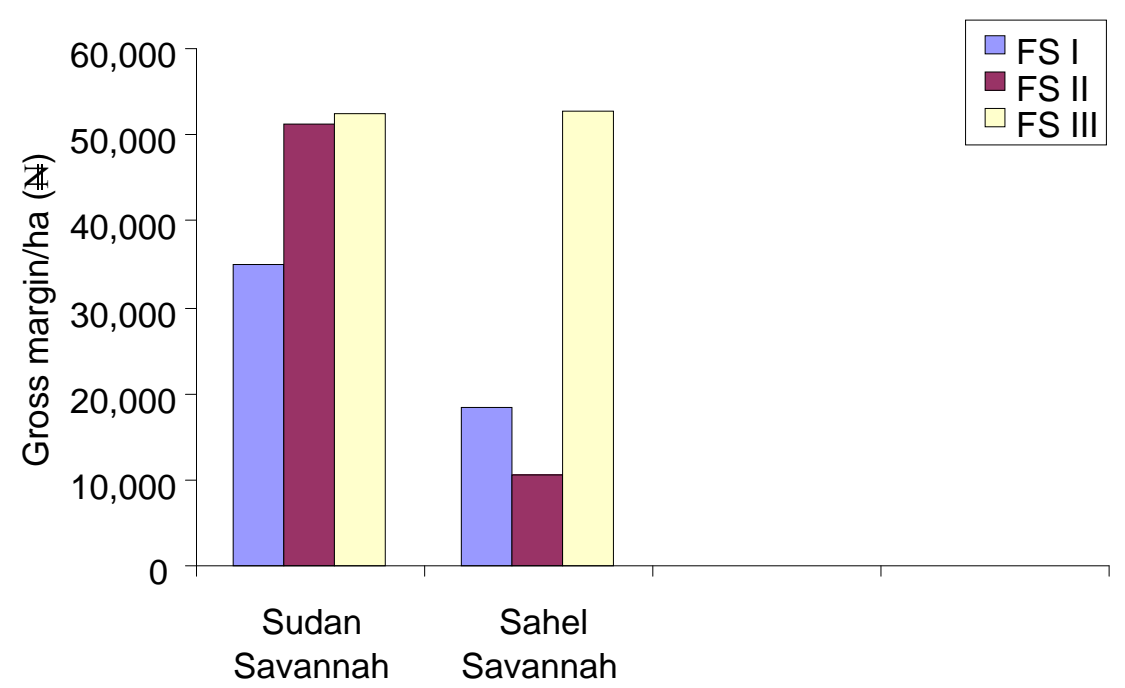

Fig. 3 Comparison of gross margin from farming systems.

$\$ 33,025 / \mathrm{ha}$, labour and fertilizer procurement accounted for about $56.3 \%$ and $36.5 \%$ of the total variable cost, respectively. This system relies heavily on high external inputs; crops grown with irrigation include onions, pepper, cucumber, tomatoes and water melon. The average net household income in the Sudan Savannah was found to be $\$ 31,640 /$ ha. Fig. 3 shows a vivid comparison of gross margin from the three farming systems.

\section{Conclusions}

The study revealed a number of indigenous techniques used for soil moisture conservation. There was no evidence of direct intervention by the government for the construction of water harvesting structures. Available structures only exist by chance and few farmers take advantage of them. A concerted extension outreach need to be carried out in the area to sensitize the farmers on the benefits of using water harvesting techniques to enhance productivity and increase their income. The agriculture departments of local government authorities in the area should be encouraged to assist the farmers with the construction of water harvesting reservoirs for use in the dry season. 


\section{Acknowledgments}

The authors wish to appreciate the funding support provided by the FAO for the study. And they also gratefully appreciate the assistance provided by the field technicians of the Institute of Agricultural Research (IAR), Ahmadu Bello University, Zaria.

\section{References}

[1] Falkenmark, M. 1997. "Meeting Water Requirements of an Expanding World Population." Phil. Trans. Roy. Soc. 352: 929-36.

[2] Molden, D., Frenken, K., Barker, R., Fraiture, C., Mati, B., Svendsen, M., Sadoff, C., and Finlayson, C. M. 2007. "Trends in Water and Agricultural Development." In Water for Food, Water for Life: A Comprehensive Assessment of Water Management in Agriculture, edited by Molden, D. Colombo, Sri Lanka: Earthscan Publishers, 67.

[3] Sullivan, C. A., and Meigh, J. R. 2003. "The Water Poverty Index: Its Role in the Context of Poverty Alleviation." Water Policy 5 (5-6): 513-28.

[4] Dougherty, T. C., and Hall, A. W. 1995. "Environmental Impact Assessment of Irrigation and Drainage Projects." FAO Irrigation and Drainage Paper 53. Access December 02, 2012. http://www.fao.org/docrep/v8350e/v8350e00.htm.

[5] Food and Agricultural Organization. 2008. "Climate Change, Energy and Food Security." Presented at High
Level Conference on Food Security: The Challenges of Climate Change and Bioenergy, Rome.

[6] Adewumi, J. K., and Kolawole, A. 2002. "Water Harvesting for Dry Land Farming." Zaria Geographer 15 (1): 1-11.

[7] Natural Resources Conservation Council of Nigeria. 1992. Natural Resources Conservation Action Plan. Natural Resources Conservation Council of Nigeria Final Report.

[8] Steduto, P., and Albrizio, R. 2005. "Resource Use Efficiency of Field-Grown Sunflower, Sorghum, Wheat and Chickpea: II, Water use Efficiency and Comparison with Radiation Use Efficiency." Agric. For. Meteorol. 130 (3-4): 269-81.

[9] MaCracken, J. A., Pretty, J. N., and Conway, G. R. 1988. An Introduction to Rapid Rural Appraisal for Agricultural Development. Sustainable Agriculture Programme, International Institute for Environment and Development, London, 84.

[10] Sobowale, A., Adewumi, J. K., Otun, J. A., and Adie, D. B. 2008. "Water Resources Management of Jamaare and Misau Rivers Sub-Catchment of Komadugu Yobe River Basin, Nigeria.” Nigerian Journal of Engineering 14 (2): 54-9.

[11] Food and Agricultural Organization. 2002. "Food Insecurity: When People Must Live with Hunger and Fear Starvation." In The State of Food Insecurity in the World (SOFI), 4th ed., Rome, Italy: FAO, 355. 